\title{
MENGEMBANGKAN POTENSI DAN KECERDASAN DENGAN MENGHARGAI FITRAH ANAK
}

\author{
Moh. Yusuf Efendi \\ Bimbingan \& Konseling FKIP UNUGIRI Bojonegoro \\ efendyunu@gmail.com \\ M. Iqbal Tawakkal \\ Bimbingan \& konseling, FKIP UNUGIRI Bojonegoro \\ miqbal.tawakkal@yahoo.com
}

\begin{abstract}
Intelligence is the custom to create new products that have cultural values and habits to solve problems personally. Intelligence can be seen from various dimensions, because intelligence is more focused on the process to achieve the best conditions ahir. This is in accordance with the nature of children who are basically sacred and have the potential to always develop so that requires the process of actualization through education both from the community, school and parents. The task of parents is to find the child's ability by being more sensitive to the activities of children that can be interpreted as ability. The parent must be a unyielding explorer in discovering his son's abilities.
\end{abstract}

Keywords: potential, Intelligence, nature of children

\section{ABSTRAK}

Intelijen adalah kebiasaan untuk menciptakan produk-produk baru yang memiliki nilai-nilai budaya dan kebiasaan untuk memecahkan masalah secara pribadi. Kecerdasan dapat dilihat dari berbagai dimensi, karena kecerdasan lebih difokuskan pada proses untuk mencapai kondisi terbaik ahir. Hal ini sesuai dengan sifat anak-anak yang pada dasarnya sakral dan memiliki potensi untuk selalu berkembang sehingga memerlukan proses aktualisasi melalui pendidikan baik dari masyarakat, sekolah maupun orang tua. Tugas orang tua adalah menemukan kemampuan anak dengan menjadi lebih peka terhadap aktivitas anak yang dapat diartikan sebagai kemampuan. Orang tua harus menjadi penjelajah pantang menyerah dalam menemukan kemampuan putranya.

Kata kunci: potensi, Kecerdasan, sifat anak-anak

\section{A. Pendahuluan}

Setiap anak yang lahir ke dunia ini pasti memiliki bakat dan kecerdasan masing - masing.

Kalimat tersebut sudah pasti benar, dan sebagai orang tua haruslah menyadari akan potensi dan kecerdasan anak dari fitrah anak itu sendiri. Pada hakekatnya dalam diri seorang anak terdapat dua dimensi yaitu jasmani dan ruhani. Sebagai orang tua, kita seharusnya memperhatikan kedua dimensi tersebut karena jasmani dan ruhani 
Pendas : Jurnal IImiah Pendidikan Dasar, ISSN Cetak : 2477-2143 ISSN Online : 2548-6950 Volume II Nomor 2, Desember 2017

itu selalu berkembang dan menimbulkan kebutuhan - kebutuhan mereka. Orang tua harus memenuhi klebutuhan itu secara adil. Namun, kebanyakan orang tua dalam melihat perkembangan anaknya hanya pada satu dimensi saja, yaitu jasmani dan mengabaikan ruhani yang memang abstrak.(Munif Chatib,2012:2)

Dalam ilmu psikologi perkembangan juga dijelaskan ada dua dimensi yakni fisiologi dan psikologi. Fisiologi melihat perkembangan anak pada jasmaninya, sementara psikologi melihat perkembangan anak pada kehidupan masyarakat yang mengarah pada perkembangan mental, daya nalar (kognitif), perasaan (afektif) dan aktivitas(motorik).(Abu Bakar Baraja, 2007:3-4)

Banyak kasus yang terjadi di masyarakat terkait keluahan orang tua atas kenakalan anak mereka, sejak kecil bahkan hingga dewasa. Sehingga membuat orang tua tidak tahan dan berakhir dengan tragedi yang dimuli dari luapan emosi berupa kemarahan, bentakan - bentakan, kekerasan fisik, pengusiran dari rumah, hingga bunuh diri atau pembunuhan. Tragedi yang seperti itu dapat terjadi pada kedua pihak, terkadang anak sebagai korban atau orang tua menjadi korban.

Melihat begitu fatalnya masalah yang ditimbulkan, mengapa sorang anak berprilaku merusak dan memusuhi orang tua, guru, atau temannya? Lalu bagaimana sikap orang tua ketika melihat prilku anaknya yang sangat negatif tersebut? Untuk menjawab dan mengatasinya, maka orang tua perlu merubah pola pikir dari yang negatif menjadi positif, orang tua harus menyadari bahwa setiap anak yang dilahirkan mempunyai fitrah ilahiyah yaitu kekutan untuk mendekati tuhan dan cenderung berprilaku baik. Fitrah ini layaknya fondasi dalam sebuah bangunan, yaitu berupa ruh yang cenderung mengenal tuhannya. Dengan fitrahnya itu, manusia sesungguhnya mempunyai kecenderungan pada agama atau kecenderngan mutlak pada perilaku perilaku baik.

\section{B. Analisis}

\section{Pengertian kecerdasan}

Kecerdasan merupakan kemampuan seseorang untuk menyelesaikan suatu permasalahan . Pembicaraan mengenai makna 
Pendas : Jurnal IImiah Pendidikan Dasar, ISSN Cetak : 2477-2143 ISSN Online : 2548-6950 Volume II Nomor 2, Desember 2017

kecerdasan sangatlah luas. Teori teori kecerdasan terus berkembang mulai dari Plato, Aristoteles, Darwin, Alferd Binet, Stanberg, Piaget sampai Howard Gardner. Perkembangan yang pesat ini mengerucut pada pola yang sama, yaitu makna kecerdasan banyak ditentukan oleh faktor situasi dan kondisi yang terjadi pada saat teori tersebut muncul. Pada ahirnya makna kecerdasan sangatlah bergantung pada banyaknya kepentingan eksternal dari hakikat kecerdasan itu sendiri. Kepentingan eksternal tersebut meliputi kepentingan politis, keturunan, keunggulan ras dll.

Teori kecerdasan mengalami puncak perubahan paradigma pada tahun 1983 saat Dr. Howard Gardner pemimpin project zero harvard universitymengumumkan perubahan makna kecerdasan dari pemahaman sebelumnya. Teori multiple intelegences belakangan ini banyak diikuti oleh psikolog dunia yang berpikiran maju. Teori ini awalnya hanya dipakai dalam wilayah psikologi, akan tetapi teori ini berkembang sampai ranah edukasi bahkan merambah pada dunia profesional diperusahaan perusahaan besar.
Kecerdasan seseorang tidak mungkin dibatasi oleh indikator indikator yang ada dalam achivement tes (tes formal). Hal in dikarenakan kecerdasan seseorang selalu berkembang (dinamis) dan tidak statis. Menurut Gardner sumber kecerdasab seseorang adalah kebiasaannya untuk membuat produk - produk baru yang punya nilai budaya (kreativitas)dan kebiasaanya menyelesaikan masalah secara pribadi (problem solving).

Kecerdasan seseorang bisa dilihat dari banyak dimensi, tidak hanya kecerdasan verbal atau kecerdasan logika saja. Akan tetapi kecerdasan seseorang adalah proses kerja otak seseorang sampai orang itu menemukan kondisi ahir terbaiknya. Singkatnya kecerdasan lebih dititik beratkan pada proses untuk mencapai kondisi ahir terbaiknya.

Dalam menemukan kecerdasan seorang anak, maka harus dibantu oleh lingkungannya, baik itu orang tua, sekolah maupun sistem pendidikan yang di implementasika disuatu negara. Setelah mengetahui akan kecerdasan seorang anak, maka langkah selanjutnya adalah 
Pendas : Jurnal IImiah Pendidikan Dasar, ISSN Cetak : 2477-2143 ISSN Online : 2548-6950 Volume II Nomor 2, Desember 2017

mempromosikan kemampuan atau kelebihan anak dan mengubur ketidakmampuan atau kelemahan anak. Proses menemukan inilah yang menjadi sumber kecerdasan anak.(Munif Chatif, 2012:68-79)

Kecerdasan seorang anak juga sering dikaitkan dengan faktor genetika nyang diturunkan oleh orang tuanya. Akan tetapi, hal itu bukanlah elemen pokok penentu kecerdasan seorang anak. Proses pembelajaran yang baik dan juga pendidikan yang efektif baik dari lingkungan masyarakat, keluarga maupun sekolahan juga merupakan elemen penting dalam meningkatkan kecerdasan seorang anak. Dalam usaha menigkatkan kecerdasan seorang anak, maka orang tua harus melakukan beberapa hal agar sang anak memiliki kecerdasan yang tinggi, diantaranya adalah :

a. Memberi ASI eksklusif secara konsisten

ASI merupakan bentuk kasih sayang orang tua terutama ibu kepada anaknya. Saat menyusu terdapat ikatan batin yang kuat antara ibu dengan anak sehingga banyak manfaat yang terdapat dalam ASI. (M. Saifullah Rohman, 2013:1617) b. Hindari rokok, minuman keras, dan obat terlarang saat hamil

Rokok, minuman keras dan obat- obatan terlarang merupakan bahan yangsangat berbahayabagi tubuh manusia jika dikonsumsi, apalasi bagi wanita yang sedang hamil. Sebab, zat - zat yang terkandung dalam bahan - bahan tersebut sangat berbahaya bagi janin dan kemungkinan wanita yang mengknsumsinya akan mendapatkan anak cacat lebih besar dibanding dengan wanita yang tidak mengkonsumsinya.

c. Kurangi menonton televisi

Saat ini, televisi menjadi barang yang susah untuk ditinggalkan. Banyak anak yang membuang waktu sedemikian besar hanya untuk menonton televisi. Terlalu lama menonton televisi tentunya tidak baik dalam perkembangan kemampuan kognitif seorang anakdan juga perkembangan otaknya. Anak akan kurang berkomunikasi dengan dunia nyata, karna asyik dengan dunia televisi.

d. Berlatih alat musik untuk peningkatan kemampuan verbal

Bermain musik erat kaitanya dengan kemampuan kecerdasan 
Pendas : Jurnal IImiah Pendidikan Dasar, ISSN Cetak : 2477-2143 ISSN Online : 2548-6950 Volume II Nomor 2, Desember 2017

otak. Anak yang memiliki kemampuan memainkan piano, alat gesek, atau alat musik lainya memiliki skor $15 \%$ lebih tinggi dalam kemampuan verbal dibandingkan dengan anak yang tidak bisa memainkan alat musik. Hal ini menunjukan korelasi antara kemampuan verbal dengan kecerdasan seorang anak.

e. Menjaga kesehatan

Kesehatan merupakan harta yang tak ternilai. Didalam tubuh yang sehat terdapat otak yang sehat pula. Kesehatan yang dimiliki seseorang akan meningkatakan kemampuan kecerdasan otak. Sebab, kesehatan dapat memberikan kesempatan bagi seseorang ntuk mencari ilmu seluas - luasnya.

f. Melatih anak menjadi penyabar

Seorang anak yang tidak cepat emosi dan sabar, serta tidak cepat puas dengan apa yang telah dicapai memiliki nilai lebih tinggi dibandingkan anak yang tidak sabaran. Oleh karena itu orang tua perlu menekankan bahwa proses itu lebih penting dari pada hasil akhir, sehingga anak terbiasa untuk bersabar dan tidak instan dalam mencapai hasil akhir.

g. Membuat anak suka membaca
Membaca meupakan jendela dunia. Melatih anak untuk suka membaca dapat mengeksplorasi pengetahuan dan belajar anak secara mndiri. Namun begitu, jangan memaksa anak sebelum merekan mampu. Saat anak sudah mampu, orang tua baru mendampinginya agar lebih terarah. Membaca terkadang membosankan, sehingga orang tua perlu turut serta dalam melatih anak mencintai membaca. Saat ini, buku bukan sekedar berwujud fisik, tetapi juga ada yang berbentuk digital. Hal itu bukan menjadi persoalan untuk memperkenalkan buku pada anak. Keberhasilan pendidikan disekolah tak lepas dari pendidikan yang diajarkan oleh orang tuanya di rumah. Oleh karena itu, kesenjangan intelektual yang besar akan terjadi antara anak yang memiliki orang tua yang melek huruf dengan orang tua yang buta huruf. Orang tua yang suka membaca akan menujukan kepada anak - anak mereka bahwa membacaitu adalah hal yang menyenagkan, menarik dan bermanfaat.

h. Melatih anak untuk mandiri

Salah satu cara terbaik adalah meminta ana untuk melakukan tugas - tugas normal kehidupan secara 
Pendas : Jurnal IImiah Pendidikan Dasar, ISSN Cetak : 2477-2143 ISSN Online : 2548-6950 Volume II Nomor 2, Desember 2017

mandiri. Saat anak usia 2 atau 3 tahun, hendaknya dilatih untuk bisa berpakaian sendiri, makan sendiri, minum sendiri, dan membereskan mainan mereka sendiri. Saat anak mencapai usia 4 dan 5 tahun, dapat dilatih untuk menggunakan sendok, garpu, memasak, memakai tali sepatu, dasi, dan sebagainya. Meskipun kegiatan tersebut nampak sederhana bagi orang dewasa, namun dapat merangsang pertumbuhan otak anak.

i. Mengembangkan kepercayaan diri Anak yang memiliki kecerdasan yang tinggi biasanya memiliki tingkat kepercayaan diri yang tinggi jika dibandingkan dengan anak seusianya. Melatih anak untuk memiliki rasa kepercayaan diri perlu dilakukan sejak dini. Kepercayaan diri akan datang jika mereka melihat dua hal. Pertama, apa yang mereka lakukan tidak pernah terbayangkan sebelumnya dan mereka bisa melakukannya. Kedua, apa yang mereka lakukan itu tidak bisa dilakukan anak lain, terutama jika mereka bisa mengalahkan anak yang memiliki usia diatasnya.

j. Tidak memiliki berat badan yang berlebihan
Anak yang memiliki berat badan berlebih teryata memiliki kemampuan membaca di bawah anak yang memiliki berat badan normal. Tingginya berat badan seseorang teryata berkaitan dengan rendahnya pencapaian prestasi. Berat badan ini sering kali disebabkan karena kurangnya interaksi sosial. Anak lebih banyak menghabiskan waktu di depan televisi ataupun komputer. Padahal ada beberapa pengetahuan yang bisa meningkatkan kecerdasan anak yang hanya diperoleh melalui interaksi sosial dimasyarakat.

k. Mendidik anak melalui pendidikan anak usia dini

Pendidikan terhadap anak hendaknya dimulai sejak masih dalam kandungan dengan memberikan rangsangan rangsangan yang mampu menumbuhkan perkembangan otak. Saat uur 3 atau 4 tahun, anak dapat memperoleh pendidikan formal di PAUD. Orang tua hendakya menyadari penting pendidikan PAUDterhadap proses tumbuh kembang anak, sehingga dapt diketahui potensi yang dimilki oleh anak sejak usia dini. 
Pendas : Jurnal IImiah Pendidikan Dasar, ISSN Cetak : 2477-2143 ISSN Online : 2548-6950 Volume II Nomor 2, Desember 2017

I. Usia ayah hendaknya tidk terlalu tua saat memiliki anak

Anak dari ayah yang berusia sekitar 20ntahun memiliki nilai $3-6$ poin lebih tinggi pada tes IQ dari pada anak yang mempunyai ayah berusia dua kali lipat dari 20 tahun. Usia ayah yang terlalu tua sering kali diakaitkan dengan peningkatan resiko gangguan saraf, seperti autisme, skizofrenia atau dsleksia, dan penurunan kecerdasan.

m.Memperkenelkan kosa kata sebanyak mungkin

Diantara beberapa anak genius didunia, sebagian dari mereka mempunyai kemampuan verbal yang sangat baik.kemampuan linguistik merupakan salah satu tanda bahwa seorang anak genius. Orang tua dapat melatih anak untuk mengembangkan kemampuan linguistik dengan memperkenalkan kata - kata baru setia hari, baik dari bahasa ibu maupun bahasa asing. Kemampuan anak dalam menyerap kata hendaknya dimanfaatkan sedini mungkin, sehingga otak anak selaluberkembang mempelajari sesuatu yang baru.

n. Kurangi bermain komputer dan vidio game
Di zaman yang serba digital ini, anak memang tidak dapat dipisahkan dari perkembangan kemajuan zaman. Komputer dan vidio game menjadi hal yang sangat digandrungi oleh anak - anak. Memang ada beberapa manfaat positif dari belajar komputer. Namun apabila anak terlalu lama bermain dengan komputer juga bisa menyebabkan anak memiliki nilai yang kurang bagus. Sesuatu hal yang dilakukan secara berlebihan maka akan memberikan dampak yang negatif baik dari segi kognitif, psikomotorik dan efektif anak.

o. Berhati - hati dengan bahan pestisida saat kehamilan

Bahan kimia terutama pestisida pada produk pertanian yang sering dikonsumsi teryata sangat berbahaya bagi manusia, terutama ibu hamil. Hal ini dikarenakan pestisida merupakan senyawa kimia yang sangat rentan mempengaruhi tumbuh kembang anak sejak dalam kandungan. Anak - anak yang terkena pengaruh pestisida saat dikandungan sang ibu memiliki IQ lebih rendah sekitar 1,4\% dari pada anak yang tidak terkena kontaminasi pestisida saat dikandungan. Oleh karena itu, para ibu dan calon ibu 
Pendas : Jurnal IImiah Pendidikan Dasar, ISSN Cetak : 2477-2143 ISSN Online : 2548-6950 Volume II Nomor 2, Desember 2017

hendaknya memperhatikan konsumsi mereka demi perkembangan kecerdasan anak.

p. Menghindari junk food

Makanan junk food atau makanan cepat saji teryata tida baik bagi kesehatan anak, terutama jika dikonsumsi dalam jangka waktu lama. Oleh karena itu, untuk pertumbuhan optimal otak anak, hendaknya orang tua menghindari makanan junk food., makanan berkadar lemak tinggi, dan makanan yang tidak sehat lainya.

q. Membiasakan untuk sarapan pagi

$$
\text { Sarapan pagi memiliki }
$$
berbagai manfaat untuk kesehata maupun kecerdasan anak. Seorang anak yang sarapan pagi memiliki ingatan yang lebih baik, mampu berkonsentrasi lebih baik dan mampu belajar lebih cepat dibandingkan anak yang tidak sarapan sama sekali.

r. Melakukan permainan asah otak

Dunia anak adalah dunia bermain. Oleh karena itu orang tua harus mengerti akan dunia anak. Orang tua tidak bisa memaksakan anak untuk selalu belajar setiap saat, karena itu akan membebani mereka adan membuat belajar bukan lagi hal yang menyenangkan. Usaha yang dapat dilakukan untuk mengasah kemampuan anak dalam koridor bermain adalah dengan memberikan permainan yang edukatif dan menyenangkan.

s. Cermat memilih mainan

Sejak kecil anaka telah diberikan mainan. Apabila orang tua tepat dalam memilihkan mainan bagi anaknya, mainan tersebutpabila orang tua tepat dalam memilihkan mainan bagi anaknya, mainan tersebuttidak hanya sekedar berfungsi sebagai hiburan, namun juga dapat berfungsi sebagai media edukasi untuk memberikan stimulus bagi perkembangan kogitif, motorik dan kreativitas anak.(M. Saifullah Rohman, 2013:18 - 28)

\section{Hakekat Fitrah Anak}

Musnad Ahmad no. 14277

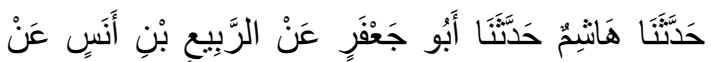

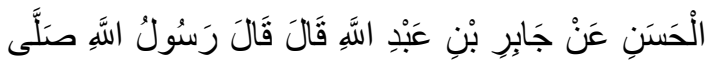

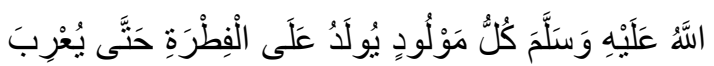

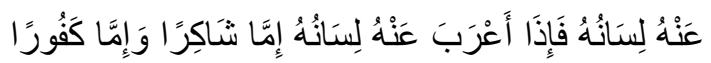

Artinya : Telah bercerita kepada kami Hasyim telah bercerita kepada kami Abu Ja'far dari Ar-Robi' bin Anas dari Al Hasan dari Jabir bin Abdullah berkata; Rasulullah shallallahu'alaihi wasallam 
Pendas : Jurnal IImiah Pendidikan Dasar, ISSN Cetak : 2477-2143 ISSN Online : 2548-6950 Volume II Nomor 2, Desember 2017

bersabda: "Setiap anak dilahirkan di atas fithrah (Islam), hingga lisannya menyatakannya (mengungkapkannya), jika lisannya telah mengungkapkannya, dia nyata menjadi orang yang bersyukur (muslim) atau bisa juga menjadi orang yang kufur".

Pada dasarnya setiap anak memiliki potensi untuk menjadi pribadi yang suci dan berakhlak mulia. Akan tetapi potensi tersebut bisa saja berubah manakala seorang anak terpengaruh dengan hal yang mempengaruhinya berupa pendidikan yang merusak baik yang berasal dari masyarakat, keluarga maupun lingkungan pendidikan.

Anak juga merupakan kebanggaan bagi orang tuanya, dan pastinya setiap orang tua pasti menginginkan anak yang bisa dibanggakan. Allah SWT berfirman dalam surah al kahfi ayat 46 :
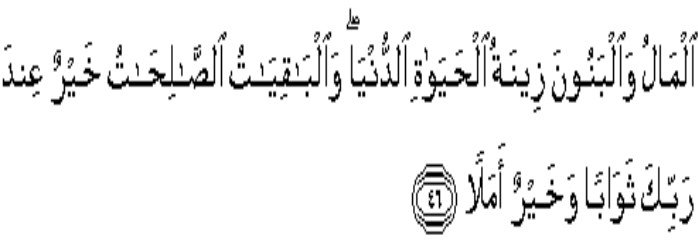

Artinya :"harta dan anak-anak adalah perhiasan kehidupan dunia tetapi amalan-amalan yang kekal lagi saleh adalah lebih baik pahalanya di sisi Tuhanmu serta lebih baik untuk menjadi harapan".

Namun pada kenyataannya, tidak semua anak demikian. Di ayat yang lain allah SWT berfirman :

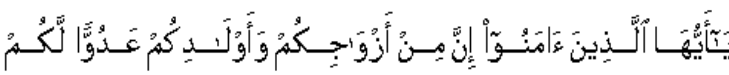

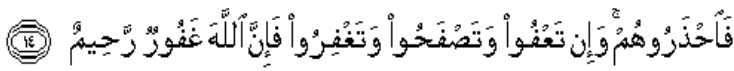

Artinya : "Hai orang-orang mukmin, Sesungguhnya di antara isteri-isterimu dan anakanakmu ada yang menjadi musuh bagimu Maka berhatihatilah kamu terhadap mereka dan jika kamu memaafkan dan tidak memarahi serta mengampuni (mereka) Maka Sesungguhnya Allah Maha Pengampun lagi Maha Penyayang".

Melihat dari redaksi ayat diatas, maka kita bisa tahu bahwa anak bisa mendatangkan kebanggaan bagi orang tuanya dan juga bisa mendatangkan malapetaka bagi orang tuanya. Ketekunan serta 
Pendas : Jurnal IImiah Pendidikan Dasar, ISSN Cetak : 2477-2143 ISSN Online : 2548-6950 Volume II Nomor 2, Desember 2017

kasih sayang orang tua dalam mengasuh dan memberikan pendidikan kepada anak sangatlah penting, hal ini akan menentukan masa depan dari anak itu sendiri kelak. Orang tua harus dapat meningkatkan kualitas anak dengan menanamkan nilai-nilai yang baik dan akhlak yang mulia disertai dengan ilmu pengetahuan agar dapat tumbuh manusia yang mengetahui kewajiban dan hak-haknya. Jadi, tugas orang tua tidak hanya sekadar menjadi perantara adanya makhluk baru dengan kelahiran, tetapi juga mendidik dan memeliharanya.

\section{Hubungan Antara Fitrah Anak}

\section{Dengan Kecerdasan}

Di dalam al qur'an dijelaskan bahwa manusia memiliki fitrah, fitrah ialah potensi (pola dasar). Karena fitrah merupakan pola dasar, maka fitrah itu baru memiliki arti bagi kehidupan manusia setelah dikembangkan secara optimal. Fitrah manusia meliputi tiga dimensi, yaitu:

Pertama, fitrah jasmanifitrah ini merupakan aspek biologis yang dipersiapkan sebagai wadah fitrah rohani. la memiliki arti bagi kehidupan manusia ountuk mengembangkan proses biologisnya.
Daya ini disebut dengan daya hidup. Meskipun daya hidup sifatnya abtrak, akan tetapi ia belum mampu menggerahkan tikah laku. Tingkah laku baru terwujud jika fitrah jasmani ini sudah ditempati fitrah rohani. Proses ini terjadi pada manusia ketika berusia empat bulan dalam kandugan.

Kedua, fitrah ruhaniah. Fitrah ini merupakan aspek psikis manusia. Aspek ini tercipta dari alam amar allah yang sifatnya gaib. la diciptakan untuk menjadi subtansi dan esensi pribadi manusia. Eksistensinya tidak hanya pada imateri saja akan tetapi juga di alam materi setelah bergabung dengan jasmani, sehingga ia lebih dahulu dan lebih abadi dari pada fitrah jasmani.

Ketiga, fitrah nafs. Fitrah ini merupakan aspek psiko-fisik manusia. Aspek ini merupakanpanduan integral (totalitas manusia)antara fitrah jasmani (biologis) dengan fitrah ruhani (psikologis), sehingga dinamakan psiko-fisik. la memiliki tiga komponen pokok yaitu qolbu, akal dan nafsu yang saling berinteraksi dan berwujud dalam kepribadian manusia. Fitrah ini diciptakan untuk mengakrualisasikansemua rencana 
Pendas : Jurnal IImiah Pendidikan Dasar, ISSN Cetak : 2477-2143 ISSN Online : 2548-6950 Volume II Nomor 2, Desember 2017

dan perjanjian Allah dengan manusia dibawah alam arwah. (Saipul Anwar, 2006:138-139)

Semua fitrah tersebut bersifat potensial dan perlu adanya upaya tertentu untuk mengaktualisasikannya. Di dalam kehidupan manusia upaya untuk mengaktualisasikan ini disebut sebagai pendidikan. Dengan demikian maka fungsi pendidikan adalah mengaktualisasikan fitrah manusia sesuai dengan kehendak sang pencipta. Dalam proses aktualisasi fitrah manusia tersebut, diperlukan dukungan atau peran aktif dari beberapa pihak seperti lingkungan, masyarakat, sekolah dan keluarga.

\section{Kesimpulan}

Kecerdasan

merupakan kemampuan seseorang untuk menyelesaikan suatu permasalahan . Pembicaraan mengenai makna kecerdasan sangatlah luas. Akan tetapi semua argumen tersebut mengerucut pada pola yang sama, yaitu kecerdasan banyak ditentukan oleh faktor situasi dan kondisi, banyaknya kepentingan eksternal yang meliputi kepentingan politis, keturunan, keunggulan ras dll dari hakikat kecerdasan itu sendiri. Kecerdasan seseorang tidak dibatasi oleh indikator - indikator yang ada dalam achivement tes (tes formal). Karena kecerdasan seseorang adalah kebiasaannya untuk membuat produk - produk baru yang punya nilai budaya (kreativitas)dan kebiasaanya menyelesaikan masalah secara pribadi (problem solving). Selain itu, Kecerdasan seseorang juga bisa dilihat dari banyak dimensi, tidak hanya kecerdasan verbal atau kecerdasan logika saja. namun kecerdasan lebih dititik beratkan pada proses untuk mencapai kondisi ahir terbaiknya.

Fitrah anak pada dasarnya adalah suci, yang memiliki potensi untuk selalu berkembang dan memerlukan proses aktualisasi melalui pendidikan baik dari lingkungan masyarakat, sekolah dan orang tua. Sebagai orang tua kita harus memahami akan hakekat anak yang memiliki dimensi jasmani dan dimensi rohani, dan memberikan pendidikan terhadap kedua dimensi tersebut. Jika orang tua mampu mengahargai dan mengoptimalkan kedua dimensi tersebut dengan memberikan hal - hal yang baik. Maka orang tua akan mampu 
mengembangkan potensi dan kecerdasan anak melalui fitrahnya. Anak memiliki kemampuan seluas samudra, kemampuan kognitif yang dapat menghasilkan daya pikir positif, kemampuan psikomotorik yang menghasilkan karya yang bermanfaat dan penampilan yang luar biasa, serta kemampuan afektif yang menghasilkan nilai dan karakter yag manusiawi sesuai dengan fitrah anak itu sendiri.

\section{DAFTAR PUSTAKA}

\section{Buku :}

Bakar, Abu, baraja. Psikologi perkembangan : tahapan dan aspek - aspeknya mulai dari 0 tahun sampai akil baligh. Jakarta :studia press. 2007

Chatif Munif, orang tuanya manusia. Bandung : PT Mizan Pustaka, Cet I 2012, Cet V \&VI 2013.

Chatif Munif, sekolahnya manusia. Bandung : PT Mizan Pustaka, Cet I 2009, Cet XIII 2012, Cet XIV, Cet XV 2012

\section{Artikel :}

Bari, fatchul (2017). One day one hadist : anak prestasi vs frustasi.

\section{Journal :}

Saipul Anwar, Hakekat manusia (manusia dimata filosof dan al qur'an serta kajian tentang inti manusia), journal pendidikan agama-ta'lim vol 4 No.2, 2006 